\title{
Brasil e Canadá
}

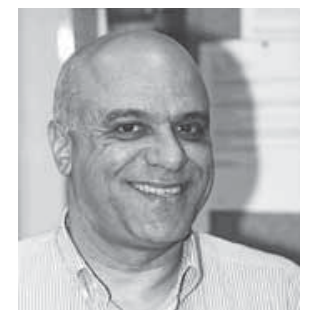

Eduardo H. Diniz FGVEAESP

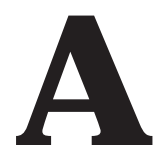

produção de multimídia em Montreal não pára de crescer. Um relatório produzido pelo Observatório da Cultura e Comunicações de Quebec, no ano passado, mostra que das cerca de 340 empresas envolvidas com produção de multimídia no Quebec, incluídas aí a produção de videogames, programas, computação gráfica, animação, digitalização, processamento e integração de áudio e vídeo, 250 delas têm base em Montreal.

Apesar do faturamento global de mais de US\$ 300 milhões por ano, a maioria dessas empresas é de pequeno ou médio porte, com menos de $20 \%$ delas faturando mais de US\$100 mil anuais. É também característico dessa indústria o uso intensivo de mão-de-obra especializada, de modo que $60 \%$ de seus custos são destinados a pagamento de salários.

Entretanto, a grande demanda dessa indústria está ameaçada justamente pela mão-de-obra ou falta dela. Quer dizer, ao mesmo tempo em que as empresas aumentam suas vendas, cresce o número de clientes e de projetos produzidos. Portanto elas precisam ser alimentadas por mão-de-obra de programadores, designers e uma gama de profissionais competentes. $\mathrm{Na}$ prática, isso se reflete num grande esforço coletivo de governo, universidades, escolas especializadas e das próprias empresas. Até as escolas de administração estão aproveitando este bom momento para desenvolver cursos de gestão de projetos voltados especificamente para esse mercado.

Todo o sucesso dessa indústria no Canadá se deve a uma política consistente de apoio do governo mediante incentivo fiscal e programas de financiamento específicos. Como reflexo, um grande número de empresas dos EUA tem interesse em consolidar parcerias com as empresas canadenses de multimídia, particularmente as de Montreal. É o caso de Disney, Warner Brothers e Universal, o que permite às empresas locais desenvolver uma forte reputação junto ao mercado americano e europeu.

E no Brasil? Observamos um desenvolvimento semelhante da indústria de software no país? Apesar de falarmos português, se tivéssemos uma política consistente para o desenvolvimento do setor, particularmente para 0 de multimídia e games, teríamos uma oportunidade única de entrar pela porta da frente no mercado mundial de tecnologia de informação.

Isso porque software é cultura e, como indústria cultural, deveria ser valorizado na defesa de nossos interesses mais fundamentais. Além disso, a indústria de software, especialmente a de games e multimídia, é bastante aberta à diversidade. Games de futebol, por exemplo, já são muito populares pelo mundo, mas desenvolvidos inteiramente fora do Brasil. Por enquanto, só resta esperar: quem sabe ainda teremos um game em que se monta uma escola para desfilar na avenida? 